\title{
Post-partum anoestrus in Anglo-Nubian and Saanen goats raised in semi-arid of North-eastern Brazil
}

\author{
V.J.F. Freitas ${ }^{\mathrm{a}, *}$, D. Rondina ${ }^{\mathrm{a}}$, D.M. Nogueira ${ }^{\mathrm{a}}$, A.A. Simplício ${ }^{\mathrm{b}}$ \\ ${ }^{a}$ Laboratório de Fisiologia e Controle da Reprodução, Faculdade de Veterinária, Universidade Estadual do Ceará - FAVET, \\ Avenue Paranjana, 1700 Campus do Itaperi, Fortaleza, Ceará CEP 60740-000, Brazil \\ ${ }^{\mathrm{b}}$ Centro Nacional Pesquisa Caprinos (EMBRAPA-CNPC), Sobral, Ceará 62150-000, Brazil
}

Received 4 March 2003; received in revised form 18 May 2004; accepted 1 June 2004

\begin{abstract}
The aim of this study was to verify the length of post-partum anoestrus (PPA) in Anglo-Nubian and Saanen goats raised in North-eastern Brazil. Thirty-four Anglo-Nubian and 25 Saanen goats were used and the following parameters were observed: parity (order I or II), type of parturition (single or multiple), length of PPA, type of oestrous cycle, milk production and body condition score (BCS). No significant difference $(P>0.05)$ was observed between breeds for PPA length. Concerning order I, Saanen goats showed a higher PPA when compared to Anglo-Nubian $(P<0.05)$. In both breeds, order I goats showed a higher PPA than order II $(P<0.05)$. Concerning the type of parturition, no significant difference was observed for the length of PPA. Anglo-Nubian goats showed a shorter first oestrous cycle length (mean \pm S.E.M.) $(23.89 \pm 5.64$ days) when compared to Saanen goats $(46.20 \pm 9.50$ days $)(P<0.05)$. For both breeds it was observed a greater proportion of long oestrous cycles $(P<0.05)$. Saanen goats showed higher daily milk production in comparison to Anglo-Nubian breed $(P<0.001)$. A significant fall in BCS was observed $(P<0.05)$ in both breeds. In conclusion, when raised in North-eastern Brazil, Saanen goats showed more efficient milk production but presented a longer PPA in primiparous females.
\end{abstract}

(C) 2004 Elsevier B.V. All rights reserved.

Keywords: Goats; Reproduction; Post-partum anoestrus; Semi-arid; Brazil

\section{Introduction}

The Brazilian goat herd is estimated at 8.2 million and approximately $90 \%$ is exploited in the Northeastern region (IBGE, 1998). The herd in this region consists mainly of mixed and local breed animals that are characterized by low milk production.

\footnotetext{
* Corresponding author. Tel.: +55-85-299-2761; fax: +55-85299-2740.

E-mail address: vjff@uece.br (V.J.F. Freitas).
}

Although the importance of preserving the native types was recognized (Shelton and Figueiredo, 1988), goat milk producers in this region saw the need in the 1930s to import specialized breeds, such as AngloNubian and Saanen, to improve production indexes. Therefore, for more than 50 years these animals have been used as pure breed or in crosses with mixed breed animals.

Goats are photoperiod dependent so those from temperate climates may present different reproductive behavior when exploited in regions with a subtropical or tropical climate (Delgadillo and Malpaux, 1996). 
Data on goat reproductive behavior in temperate climates is abundant in the literature (Chemineau et al., 1988; Ricordeau et al., 1984; Shelton, 1978) but there is little data on animals reared in the tropics.

The start of oestrous activity during the postpartum period is important to obtain a suitable kidding interval (Devendra and McLeroy, 1982). Furthermore, some reproductive parameters should be determined so that they can be used rationally and consequently improve the productivity of the breeds from temperate climates exploited in the Brazilian semi-arid region.

In sheep, it is known that factors such as suckling, body condition, breed and season can alter the length of post-partum anoestrus (PPA) (Peters and Lamming, 1990). However, there is little information on goats in general and especially on those breeds from temperate climates exploited in tropical climates (Lopes Junior et al., 2001).

The objective of the present study was to determine the length of the PPA in Anglo-Nubian and Saanen goats exploited in North-eastern Brazil, considering the effects of parity, type of parturition, body condition score (BCS) and milk production.

\section{Material and methods}

\subsection{Experiment location}

The experiment was carried out at the National Center for Goat Research, located in Sobral, $3^{\circ} 42^{\prime}$ latitude South and $40^{\circ} 21^{\prime}$ longitude West. The region has a Savannah climate characterized by one dry season and another wet season. The annual means for rainfall, temperature and relative air humidity are $821.6 \mathrm{~mm}, 26.6{ }^{\circ} \mathrm{C}$ and $67.9 \%$, respectively (Funceme, 1999).

\subsection{Experimental conditions and animal management}

A total of 59 animals was used, 34 Anglo-Nubian and 25 Saanen. At the beginning of the experiment, the mean age $( \pm$ S.E.M.) was $1.69 \pm 0.11$ and $1.53 \pm 0.14$ years, for Anglo-Nubian and Saanen goats, respectively. The goats were submitted to natural mating from March to April and the kidding occurred in August and September, during the dry season. The kids were separated from their mothers immediately after birth.

The experimental animals were submitted to semiintensive management, with access to pasture (Leuucaena leucocephala) for $2-3 \mathrm{~h}$ a day. The goats also received elephant grass (Pennisetum purpureum) chopped in the hod ad libitum and also had free access to water and mineral salt. Every day goats received concentrated meals based on $40.0 \%$ soybean meal, $56.6 \%$ tritured maize, $2.8 \%$ bicalcium phosphate and $0.6 \%$ sodium chloride, at the ratio of $1.2 \mathrm{~kg}$ for the first $\mathrm{kg}$ of milk produced and from then another $200 \mathrm{~g}$ for each additional $\mathrm{kg}$ of milk.

\subsection{Anoestrus and post-partum sexual behavior}

The PPA was considered to be the period between partum and the occurrence of the first oestrus. The oestrus was detected twice a day, in the morning and in the afternoon $(07: 00 \mathrm{~h}$ and 16:00 h), beginning 1 week after partum for 200 days and was carried out with the aid of two ovariectomized females androgenized by weekly intramuscular injections of $0.5 \mathrm{mg}$ testosterone cipionate per $\mathrm{kg}$ of live weight. The goats were considered in oestrus when accepted mounting by the androgenized female. The length of the first post-partum oestrous cycle was classified according to Chemineau et al. (1993), as short ( $<17$ days), normal (17-25 days) or long ( $>25$ days) cycle.

\subsection{Parity and type of parturition}

The parity and the type of parturition were recorded at the moment of partum. The parity was grouped in order I for the first and second parities and order II for the other parities. The type of parturition was classified as simple (one kid) or multiple (two or more kids).

\subsection{Milk production and body condition score}

The milk production per goat was registered starting 1 week after partum and then at 15 days interval during 25 weeks. The goats were also submitted to BCS assessment from partum until the lactation peak, at 2 weekly intervals $(14,28,42$ and 56 days after partum). This assessment was always carried out by 
Table 1

Age at partum and length of PPA (mean \pm S.E.M.) in Anglo-Nubian and Saanen goats raised in semi-arid region of North-eastern Brazil

\begin{tabular}{llll}
\hline Breed & $n$ & Age at partum (days) & Length of PPA (days) \\
\hline Anglo-Nubian & 29 & $1024.59 \pm 92.34$ & $78.93 \pm 7.61$ \\
Saanen & 19 & $1129.00 \pm 142.21$ & $95.26 \pm 11.80$ \\
\hline
\end{tabular}

Different letters, in the same column, are statistically different $(P<0.05)$.

the same technician, following the score proposed by Morand-Fehr and Hervieu (1999).

\subsection{Statistical analyses}

All calculations were performed with the SAS computer program. The PPA period was submitted to an analysis of variance (ANOVA) using the GLM procedure. The sources of variation tested in the model were breed, parity, type of parturition, milk production and their interactions. Comparisons among BCS within breed were performed by the Duncan test, while the other comparisons between breeds were performed by the $t$-test. Differences between percentages were tested by $\chi^{2}$-test. The GLM procedure was used to evaluate the relationship between the milk production of each breed from 0 to 56 days post-partum. Regression slopes were compared by the CONTRAST option of the GLM procedure. Correlation among PPA, parity, BCS at partum, 14, 28, 42 and 56 days were obtained by the Pearson test. Only animals exhibiting oestrus within 200 days after partum were considered for analysis
Table 2

Mean length ( \pm S.E.M.) of PPA, according to the parity and the type of parturition, in Anglo-Nubian and Saanen goats raised in semi-arid region of North-eastern Brazil

\begin{tabular}{lcc}
\hline Parameters & PPA (days) & \\
\cline { 2 - 3 } & Anglo-Nubian & Saanen \\
\hline Parity & & \\
$\quad$ Order I & $89.10^{\mathrm{aA}} \pm 9.73(20)$ & $133.50^{\mathrm{aB}} \pm 12.71(10)$ \\
Order II & $56.33^{\mathrm{b}} \pm 7.78(9)$ & $52.78^{\mathrm{b}} \pm 5.51(9)$ \\
& & \\
Type of parturition & & \\
Single & $74.2 \pm 12.98(11)$ & $113.2 \pm 16.11(10)$ \\
Multiple & $81.8 \pm 9.58(18)$ & $75.3 \pm 15.56(9)$ \\
\hline
\end{tabular}

Different normal letters, in the same column, are significantly different $(P<0.05)$. Different capital letters, in the same line, are significantly different $(P<0.05)$.

(Anglo-Nubian $=29$ and Saanen $=19$ ). Results were expressed as mean \pm S.E.M. and differences were assumed statistically significant when $P<0.05$.

\section{Results}

\subsection{Post-partum anoestrus}

Homogeneity in the age at partum for both the breeds was ascertained. No significant difference was detected between the breeds for the mean length of PPA (Table 1). It was observed that $14.7 \%(5 / 34)$ of the Anglo-Nubian and $24.0 \%(6 / 25)$ of the Saanen goats did not show oestrus until 200 days after

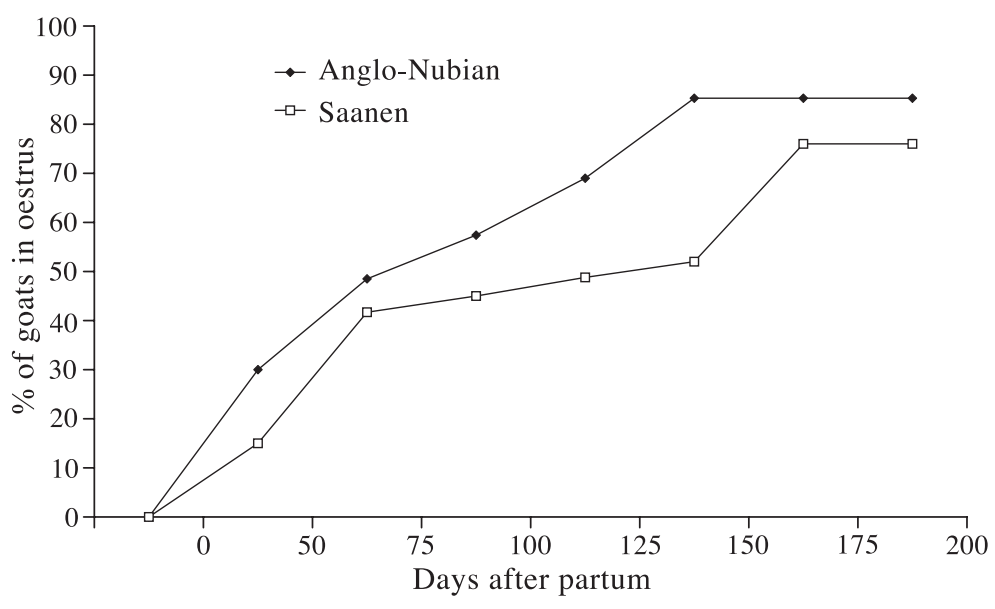

Fig. 1. Cumulative occurrence (\%) of oestrus after partum in Anglo-Nubian and Saanen goats raised in semi-arid region of North-eastern Brazil. 
Table 3

Mean ( \pm S.E.M.) of milk production, proportion (\%) of type of parturition (single or multiple) and oestrous cycles (short, normal or long), according to the parity in Anglo-Nubian and Saanen goats raised in semi-arid region of North-eastern Brazil

\begin{tabular}{|c|c|c|c|c|}
\hline \multirow[t]{2}{*}{ Parameters } & \multicolumn{2}{|l|}{ Parity order I } & \multicolumn{2}{|l|}{ Parity order II } \\
\hline & Anglo-Nubian & Saanen & Anglo-Nubian & Saanen \\
\hline $\begin{array}{l}\text { Milk } \\
\text { production } \\
(\mathrm{kg})\end{array}$ & $\begin{array}{l}17.49^{\mathrm{Aa}} \pm \\
0.55\end{array}$ & $\begin{array}{l}24.62^{\mathrm{B}} \pm \\
1.64\end{array}$ & $\begin{array}{l}22.75^{\mathrm{Ab}} \pm \\
0.75\end{array}$ & $\begin{array}{l}27.56^{\mathrm{B}} \pm \\
1.84\end{array}$ \\
\hline \multicolumn{5}{|l|}{ Parturition } \\
\hline Single & $45 \%(9)$ & $70 \%(7)$ & $22 \%(2)$ & $33 \%(3)$ \\
\hline Multiple & $55 \%(11)^{\mathrm{A}}$ & $30 \%(3)^{\mathrm{B}}$ & $78 \%(7)$ & $67 \%(6)$ \\
\hline \multicolumn{5}{|c|}{ Oestrous cycle } \\
\hline Short & $20 \%(4)^{\mathrm{aA}}$ & $0 \%(0)^{\mathrm{aB}}$ & $33 \%(3)$ & $11 \%(1)^{\mathrm{a}}$ \\
\hline Normal & $20 \%(4)^{\mathrm{a}}$ & $20 \%(2)^{\mathrm{ab}}$ & $22 \%(2)$ & $22 \%(2)^{\mathrm{ab}}$ \\
\hline Long & $60 \%(12)^{b}$ & $80 \%(8)^{\mathrm{b}}$ & $44 \%(4)$ & $67 \%(6)^{\mathrm{b}}$ \\
\hline
\end{tabular}

Different normal letters, in the same column, are significantly different $(P<0.05)$. Different capital letters, in the same line, are significantly different $(P<0.05)$. a-c: oestrus in the same breed; A, B: oestrus between breed in the same parity.

partum, but no statistical significance was detected $(P>0.05)$ (Fig. 1).

The results of ANOVA showed a significant effect regarding the parity. In both breeds, order I goats presented a longer PPA when compared to order II goats $(P<0.05)$ (Table 2$)$. When referring to order I,
Table 4

Regression equations of milk production $(\mathrm{kg})$ from 0 to 56 days after partum in Anglo-Nubian and Saanen goats raised in semi-arid region of North-eastern Brazil

\begin{tabular}{|c|c|c|c|c|c|}
\hline Breed & Equations & $R^{2}$ & RSME & $P$ & $\begin{array}{l}\text { Anglo- } \\
\text { Nubian } \\
\text { versus } \\
\text { Saanen }\end{array}$ \\
\hline Anglo-Nubian & $y=1.39+0.084 x$ & 0.89 & 0.22 & 0.001 & 0.001 \\
\hline Saanen & $y=1.22+0.159 x$ & 0.86 & 0.35 & 0.001 & \\
\hline
\end{tabular}

the Saanen goats presented longer PPA than AngloNubian goats $(P<0.05)$.

Regarding the type of parturition, there was no significant difference in the length of PPA $(P>0.05$, Table 2); although a greater percentage of multiple partum was detected in the Anglo-Nubian breed ( $62.1 \%$ vs. $47.4 \%, P<0.05)$. Concerning the order I of parity, the occurrence of multiple partum was superior in Anglo-Nubian than in Saanen breed $(P<0.05$, Table 3).

\subsection{First post-partum oestrous cycle}

The Anglo-Nubian goats presented a shorter mean oestrous cycle $(23.89 \pm 5.64$ days $)$ when compared to the Saanen goats $(46.20 \pm 9.50$ days $)$ $(P<0.05)$.

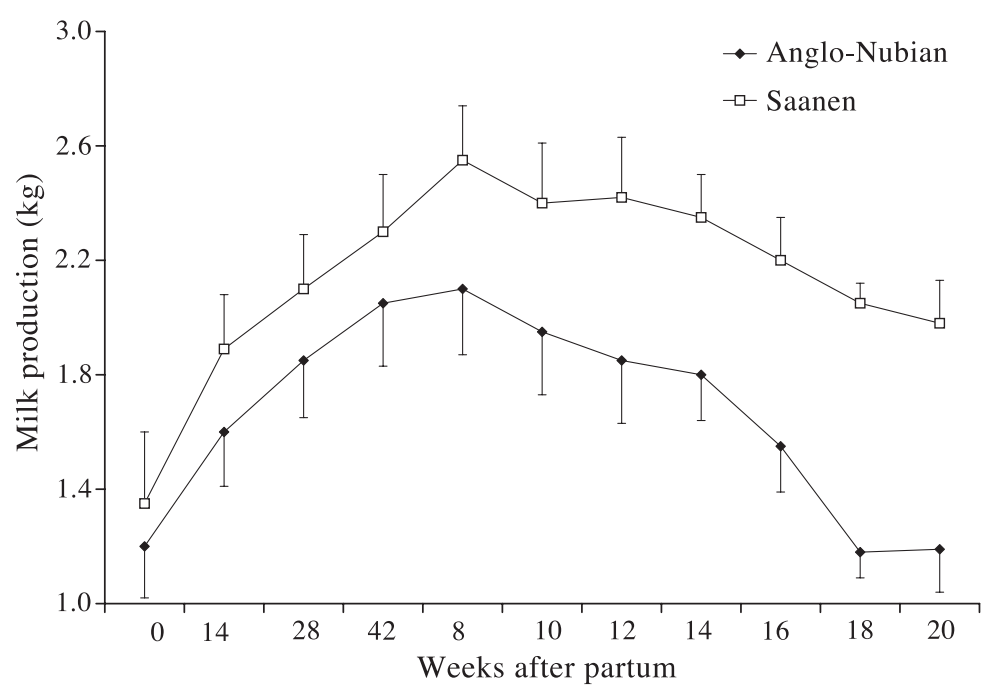

Fig. 2. Milk production $(\mathrm{kg})$ (mean \pm S.E.M.) in Anglo-Nubian and Saanen goats raised in semi-arid region of North-eastern Brazil. (a, b: $P<0.05)$. 


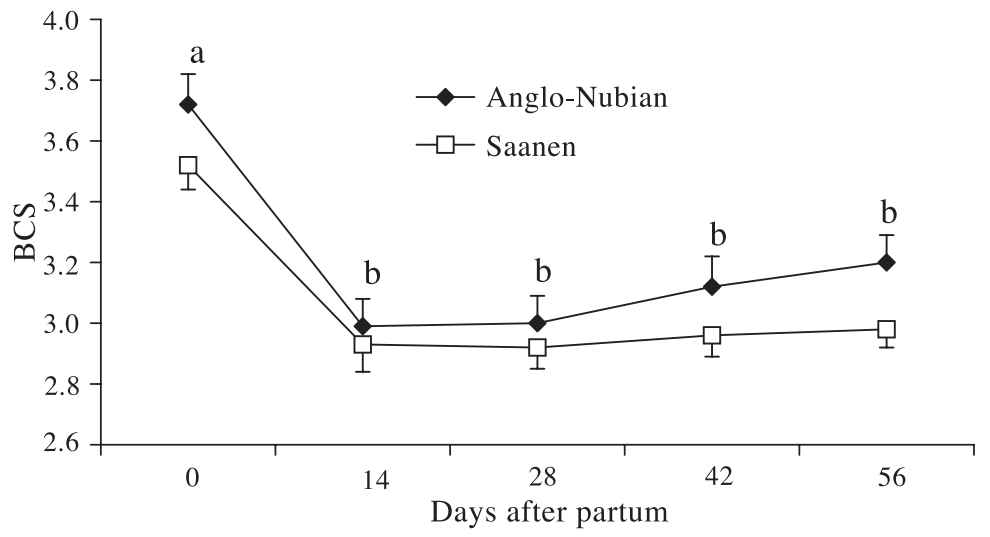

Fig. 3. Mean ( \pm S.E.M.) of BCS in Anglo-Nubian and Saanen goats at partum (day 0) and at 14, 28, 42 and 56 days after partum, when raised in semi-arid region of North-eastern Brazil.

Regarding the frequency of the types of oestrous cycles, a greater percentage of long cycles was detected $(P<0.05)$ (Table 3$)$. Furthermore, concerning order I a greater percentage of short cycles was observed in Anglo-Nubian compared to the Saanen goats $(P<0.05)$ (Table 3$)$.

\subsection{Milk production}

The total Saanen milk production was superior to Anglo-Nubian goats for both parities $(P<0.05)$ (Table 3). Anglo-Nubian goats of order I showed lower production when compared to order II $(P<0.05)$.

The milk production peak, in both breeds, was observed around 60 days post-partum (8th and 9th week) (Fig. 2). The comparison among the regression coefficients for milk production, from partum until the lactation peak, showed a superior daily production by Saanen breed $(P<0.001)$ (Table 4$)$. After this period, the comparison of the mean milk production decreased most sharply in the Anglo-Nubian breed. This fall was significant $(P<0.05)$ after the 12th week post-partum.

\subsection{Body condition score}

The comparison between the breeds showed similar values for the BCS. The BCS at partum was superior to 3.5 in the two breeds (Fig. 3). There was a decrease in the BCS after partum $(P<0.05)$ in both Saanen and Anglo-Nubian goats. After 14 days postpartum the BCS presented similar values. At the moment of the occurrence of the first oestrus (56 days post-partum) the mean BCS was $3.22 \pm 0.09$ and

Table 5

Correlation among BCS at partum (BCS 0), 14th (BCS 14), 28th (BCS 28), 42nd (BCS 42) and 56th (BCS 56) days after partum and PPA, parity (PA), type of parturition (TP) in Anglo-Nubian (AN) and Saanen (SA) goats raised in semi-arid region of North-eastern Brazil

\begin{tabular}{|c|c|c|c|c|c|c|c|c|}
\hline & \multicolumn{2}{|l|}{ BCS 0} & \multicolumn{2}{|c|}{ BCS 14} & \multicolumn{2}{|l|}{ BCS 28} & \multicolumn{2}{|c|}{ BCS 42} \\
\hline & AN & SA & AN & SA & AN & SA & AN & SA \\
\hline PPA & & $-0.45^{*}$ & & & & & & \\
\hline PA & & $0.45^{*}$ & & & & & & \\
\hline $\mathrm{TP}$ & $-0.53 * *$ & & & & $-0.37^{*}$ & & & \\
\hline \multicolumn{9}{|l|}{ BCS 0} \\
\hline BCS 14 & $0.59 * *$ & $0.78 * *$ & & & & & & \\
\hline BCS 28 & $0.60 * *$ & $0.56^{*}$ & $0.68 * *$ & $0.61 * *$ & & & & \\
\hline BCS 42 & $0.47 * *$ & & $0.60 * *$ & & $0.77 *$ & & & \\
\hline BCS 56 & $0.42 *$ & $0.60 * *$ & $0.40^{*}$ & $0.67 * *$ & $0.77 *$ & $0.61 * *$ & $0.71 *$ & \\
\hline
\end{tabular}

$* P<0.05$

$* * P<0.01$ 
$3.13 \pm 0.06$ for Anglo-Nubian and Saanen breeds, respectively $(P>0.05)$. At first oestrus post-partum the mean score achieved $87.37 \%$ of BCS at partum.

The Saanen goats presented a negative correlation between the BCS at partum and the PPA length $(P<0.05)$. For the Anglo-Nubian goats, the type of parturition was correlated negatively with the BCS at partum $(P<0.01)$ and on the 28th day after partum $(P<0.05)$ (Table 5). In the AngloNubian goats the BCS at partum was positively correlated with the scores on the 14th $(P<0.01)$, 28th $(P<0.01) 42$ nd $(P<0.01)$ and 56th $(P<0.05)$ day after partum (Table 5).

\section{Discussion}

In this study, the length of PPA was fairly high when compared to the results obtained with local or mixed breed goats in Brazil. Maia and Costa (1998) worked with Canindé goats and detected a PPA of $46.4 \pm 3.4$ days. Andrioli et al. (1992), working with mixed breed goats, observed a PPA of $52.3 \pm 3.9$ days for goats kidding during the dry season. The greater specialization of the breeds in the present study (Anglo-Nubian and Saanen vs. mixed breed) may be one of the reasons for the large interval between partum and the occurrence of first oestrus.

In temperate regions, the seasonal anoestrus and PPA in goats are present naturally at the same time resulting in an increase of length in the latter. Thus the PPA in Saanen goats reared in Europe can last from 200 to 300 days (Ricordeau et al., 1984). The length of PPA can vary substantially in tropical climate goats and food availability is the main environmental factor that determines the length of PPA (Gonzalez-Stagnaro, 1984).

The animals that did not present oestrus by the 200th day post-partum were considered to have a long PPA, therefore, it was not possible to determine when it ended. One of the causes for this long PPA is the possible occurrence of silent ovulations, that is ovulation not preceded by oestrus behavior, as described in goats by Delgadillo et al. (1997) in tropical and subtropical regions and by Corteel and Cognié (1985) in temperate regions.

Another possibility to consider is an interaction between seasonal anoestrus and PPA. Recent results obtained in our laboratory showed low oestrous ac- tivity in Saanen goats from September to December when raised in North-eastern Brazil (Freitas et al., unpublished). In Mexico, local goats display a period of anoestrus in late winter and spring. Goats giving birth in January display a period of anoestrus of about 200 days. At reverse, goats kidding in May display a much shorter post-partum interval (Delgadillo et al., 1998). The authors concluded that season of partum have a major influence on the time of reinitiation of sexual activity after partum.

Regarding the primiparous females, the longer length of PPA in Saanen breed was probably the consequence of a higher milk production of these animals (Ribeiro, 1996).

In our study, order I goats showed greater difficulty in returning to oestrous activity and consequently had a longer PPA compared to order II. It is possible that this difference is due to a better ability for the return to oestrous activity after the partum in higher parity goats. Such fact may be related to the fast uterine involution process (Fasany et al., 1987; Tielgy et al., 1982) and/or to the return of the responsiveness to GnRH after partum (Fray et al., 1995; Pelletier and Thimonier, 1975). It has also been reported that cows of third and fifth parity present a shorter PPA when compared to the first and second parity females (Gifford et al., 1989; Rekwot et al., 2000).

The absence of a significant influence of the type of parturition on PPA was also verified by Acosta (1996) who worked with mixed breed goats in Cuba. Similarly, Mbayahaga et al. (1998), studying PPA in goats in Burundi (Africa), reported that the parturition type did not affect the length of PPA nor the return of ovulatory activity after partum. However, Waldron et al. (1999) working with Boer and Spanish goats, verified that the manifestation of the first oestrus after partum was four months later in goats with multiple partum than in those with single partum.

Regarding the first post-partum oestrous cycle, the longer length detected in the Saanen females may be due to a greater difficulty in returning to the normal cyclic activity. More than $50 \%$ of oestrous cycles were considered abnormal (short or long) for both breeds. It is known that in cattle there is ovulation not preceded by oestrus in approximately $50 \%$ of the females (Inskeep, 1995) during the post-partum period. Chemineau et al. (1993), working with Creole goats, detected by the progesterone levels, that the first 
ovulation not accompanied by oestrus can occur from the third week after the partum.

The Saanen goats showed greater efficiency in milk production (lactation peak and following decrease) than the Anglo-Nubian females. However, the recovery of BCS after the period of negative energetic balance (Llewelyn et al., 1992) was similar for both breeds, confirmed by the correlation among the scores at different periods after partum.

According to Gonzalez-Stagnaro (1991) body condition is the main factor that regulates the post-partum reproductive activity in ruminants exploited in tropical regions. Ribeiro (1996) reported that the body weight of Saanen goats increased slowly, from 0.6 to $1.9 \mathrm{~kg}$ per month and the BCS was between 2.0 and 2.3 at the beginning of this period and reached 2.5-2.7, 1 month later.

The body weight and condition of the mother at partum are also important, because mothers below normal weight or with an unsatisfactory body condition at partum produce lighter kids, less milk and take longer to recover the ovarian function after partum (Andrioli et al., 1992).

The higher milk production in Saanen, comparing to Anglo-Nubian breed, was probably responsible for the negative correlation between BCS at partum and length of PPA detected in this breed. According to Maia (1998) the females that lose weight or body score after partum present a significantly longer PPA than those that do not lose body weight or body score, as was detected in the Saanen females in the present experiment. Contrarily, Mbayahaga et al. (1998) reported that there is no correlation between the manifestation of the first oestrus after partum and loss of body weight in the goats. Furthermore, Llewelyn et al. (1992) observed that the return of ovarian activity after partum occurred prior to the improvement in body condition and weight.

The negative correlation between the type of parturition and BCS for the Anglo-Nubian goats may have been due to the higher prolificacy which interferes in the mother nutritional requirements, leading to decrease in this parameter (Mani et al., 1993; Mellado et al., 1991).

In conclusion, when raised in the semi-arid region of the North-eastern Brazil, Saanen goats that are more specialized, showed more efficient milk production but presented a longer PPA in primiparous females and had greater difficulty in returning to normal oestrous behavior. Therefore, reared under the same conditions, Saanen and Anglo-Nubian goats require different management to obtain the best reproductive and productive indexes.

\section{Acknowledgements}

This work was supported by Conselho Nacional de Desenvolvimento Científico e Tecnológico (CNPq/ Brazil). V.J.F. Freitas and A.A. Simplício are senior investigators of $\mathrm{CNPq} /$ Brazil.

\section{References}

Acosta, J., 1996. Duraccion del anestro postparto de cabras mestizas en amamantamiento restringido. Rev. Cub. Reprod. Anim. 22, 31-37.

Andrioli, A., Simplicio, A.A., Machado, R., 1992. Influência da época da parição no comportamento reprodutivo pós-parto de cabras Sem Raça Definida. Pesq. Agrop. Bras. 27, 65-72.

Chemineau, P., Pelletier, J., Guerin, Y., Colas, G., Ravault, J.P., Toure, G., Almeida, G., Thimonier, J., Ortavant, R., 1988. Photoperiodic and melatonin treatments for the control of seasonal reproduction in sheep and goats. Reprod. Nutr. Dev. 28, 409-422.

Chemineau, P., Baril, G., Cognié, Y., Guérin, Y., Leboeuf, B., Orgeur, P., Vallet, J.C., 1993. Manuel de formation pour l'insémination artificielle chez les ovins et les caprins FAO, Rome.

Corteel, J.M., Cognié, Y., 1985. Aspects dynamiques de la genèse des cycles sexuels chez la chèvre française à vocation laitière. I Colloque International sur Reproduction des Caprins, Drummondville, pp. 35-43.

Delgadillo, J.A., Malpaux, B., 1996. Reproduction of goats in the tropics and subtropics. International Conference on Goats, vol. 1, pp. 785-793.

Delgadillo, J.A., Malpaux, B., Chemineau, P., 1997. La reproduction des caprins dans les zones tropicales et subtropicales. INRA Prod. Anim. 10, 33-41.

Delgadillo, J.A., Flores, J.A., Villarreal, O., Flores, M.J., Hoyos, G., Chemineau, P., Malpaux, B., 1998. Length of partum anestrus in goats in subtropical Mexico: effect of season of parturation and duration of nursing. Theriogenology 49, 1209-1218.

Devendra, C., McLeroy, G.B., 1982. Goat and Sheep Production in the Tropics. Longman, Harlow, Essex, UK.

Fasany, O.O.A., Molokwu, E.C.I., Adeboye, D.S., Dim, N.I., 1987. Gross and histological changes of the post-partum genitalia of Savana Brown goats. Anim. Reprod. Sci. 14, 65-74.

Fray, M.D., Lamming, G.E., Haresign, W., 1995. Induction of ovulation in the acyclic postpartum ewe following continuous lowdose subcutaneous infusion of GnRH. Theriogenology 43, $1019-1030$. 
Funceme, 1999. Fundação Cearense de Meteorologia e Recursos Hídricos (http://www.funceme.br).

Gifford, D.R., D’Occhio, M.J., Sharpe, P.H., Weatherly, T., Pittar, R.Y., Reeve, D.V., 1989. Return to cyclic ovarian activity following parturition in mature cows and first-calf heifers exposed to bulls. Anim. Reprod. Sci. 19, 209-212.

Gonzalez-Stagnaro, C., 1984. Comportamiento reproductivo de las razas locales de rumiantes em el tropico americano. In: Chemineau, P., Gauthier, D., Thimonier, J. (Eds.), Reproduction des ruminantes en zone tropicale, vol. 1. Les Colloques de l'INRA, Point-à-Pitre, Guadeloup, pp. 1-8.

Gonzalez-Stagnaro, C., 1991. Control y manejo de los fatores que afectan al comportamiento reproductivo de los pequenos rumiantes em el medio tropical. International Symposium on Nuclear and Related Techniques in Animal Production and Health, Viena, pp. 405-421.

IBGE, 1998. Anuário Estatístico do Brasil IBGE, Rio de Janeiro.

Inskeep, E.K., 1995. Factors that affect fertility during estrous cycles with short or normal luteal phases in post-partum cows. J. Reprod. Fertil. 49, 493-503.

Llewelyn, C.A., Ogaa, J.S., Obwolo, M.J., 1992. Plasma progesterone concentrations during pregnancy and onset of ovarian activity postpartum in indigenous goats in Zimbabwe. Trop. Anim. Health Prod. 24, 242-250.

Lopes Junior, E.S., Rondina, D., Simplício, A.A., Freitas, V.J.F., 2001. Estrous behaviour and performance in vivo of Saanen goats raised in Northeast of Brazil. Liv. Res. Rural Dev. 13, 41-50.

Maia, M.S., 1998. Efeito da condição corporal e anestro pós-parto sobre o restabelecimento da atividade ovariana de cabras Canindé. Cienc. Vet. Trop. 1, 94-98.

Maia, M., Costa, A.N., 1998. Estro e atividade ovulatória pós-parto em cabras Canindé associados ao manejo da amamentação. Rev. Bras. Reprod. Anim. 22, 35-43.

Mani, A.U., Watson, E.D., McKelvey, W.A.C., 1993. Effects of subnutrition on the components of gravids uterus in the doe. Theriogenology 40, 287-294.

Mbayahaga, J., Mandiki, S.N.M., Bister, J.L., 1998. Body weight, oestrus and ovarian activity in local Burudian ewes and goats after parturition in the dry season. Anim. Reprod. Sci. 51, 289-300.

Mellado, M., Foote, R.H., Borregi, E., 1991. Lactational performance, prolificacy and relationship to parity and bodyweight in crossbred native goats in Northern Mexico. Small Rum. Res. 6, 167-174.

Morand-Fehr, P., Hervieu, J., 1999. Apprécier l'etat corporel des chévres: l'intérêt et méthode. La Chèvre 231, 22-32.

Pelletier, J., Thimonier, J., 1975. Interaction between ovarian steroids or progestagens and LH release. Ann. Biol. Biochem. Biophys. 15, 131-146.

Peters, A.R., Lamming, G.E., 1990. Lactational anestrous in farm animals. Oxford Rev. Reprod. Biol. 12, 245-288.

Rekwot, P.L., Ogwu, D., Oyedipe, E.O., 2000. Influence of bull stimulation, season and parity on resumption of ovarian activity of zebu (Bos indicus) cattle following parturition. Anim. Reprod. Sci. 63, 1-11.

Ribeiro, S.D.A., 1996. Genetics and environmental effects on milk yield of Saanen goats in Brazilian southeast. National Congress of Genetics, Caxambu Proceedings, 1-235.

Ricordeau, G., Bouillon, A., Gaillard, A., Lajous, A., Lajous, D., 1984. Modalités et caractheristiques de reproduction chez les caprins. Bull. Technol. Insem. 20, 319-383.

Shelton, J.M., 1978. Reproduction and breeding of goats. J. Dairy Sci. 67, 994-1010.

Shelton, J.M., Figueiredo, E.A.P., 1988. Genetic resources and improvement programs. In: Johnson, W.L., Oliveira, E.R. (Eds.), Improving Meat Goat Production in the Semiarid Tropics. Sobral, Ceará, pp. 33-48.

Tielgy, A.H., Fathalia, M., Omar, M.A., Al-Dahash, S., 1982. The clinical and morphological characteristics of the uterus of the goat during the period of involution. Can. Vet. J. 23, 138-140.

Waldron, D.F., Willigham, T.D., Thompson, P.V., Eckhoff, R.G., May, B.J., 1999. Age at first estrus, ovulation rate, and age at anestrus in puberal Boer $\times$ Spanish and Spanish does. Small Rum. Res. 31, 173-176. 